\title{
ECOTOURISM DEVELOPMENT OPTIMUM STRATEGIES USING SWOT AND QSPM MODELS: A CASE STUDY OF ARDEBIL PROVINCE, IRAN
}

\author{
Bahram Imani ${ }^{1}$ \\ Mansour Rahmati ${ }^{2}$ \\ Vahed Aghaei ${ }^{3}$
}

\begin{abstract}
Tourism is the largest economic activities in the worlds and has a fast growth, status of Iran suggests that Iran's tourism industry in less than one thousandth of global revenue from

effective strategies used in the development of ecotourism is in the end, using a strategic quantity planning priorities, 20 basic strategy suggested for the ecotourism development.
\end{abstract} tourism is their portion. Among the provinces of Iran, many ecotourism attractions in Ardebil province (about 42 hot and cold mineral springs, 24 dams, 11 habitats and 35 special natural attractions, etc.), which can be a factor for sustainable development in the region. This study aimed to identify existing facilities and provide optimal solutions to assist in economic development, social and cultural development of ecotourism is in shadow, so in this research using descriptive analytical model of strategic planning (SWOT) to provide strategies and

Keywords: Ecotourism, Development, Strategic Planning, SWOT, Ardebil province

\section{1- Introduction}

Tourism is define as an activity at which done by people for Entertainment and travel to other part from their home. Tourism has been done in two inner and international levels that each them has their characteristic. Inner factors totally are rule, customs, values, ideas and force groups. In recent decade, tourism importance at international level

\footnotetext{
${ }^{1}$ Assistant Professor of Geography and Rural Planning, University of Mohaghegh Ardabili, Ardabil, Iran. Email: bahram_imani60@yahoo.com.

${ }^{2}$ Assistant Professor of Political Geography, University of Mohaghegh Ardabili, Ardabil, Iran. Email: rahmati1358@gmail.com.

${ }^{3} \mathrm{PhD}$ student in Geography and Urban Planning University of Kharazmi, Tehran, Iran. Email: aghaei.vahed@gmail.com.
} 
increased in number to tourists and level income (parvin \& ahmadi, 2013). The WTO definition of tourism, which refers to all those activities outside their normal places to spend leisure time, work and other purposes, for a period of less than one year (Zahedi, 2004 ). Writing in 1989, Pearce argued that unplanned, uncontrolled tourism growth when taken to the extreme can destroy the very resource on which it is built. Hall (1991) believed that demands for tourism planning are a response to the effects of unplanned tourism expansion. Tourism planning is usually considered as planning for tourism, a traditional view that focuses on planning for tourist developments. It places great emphasis on providing destination attractions and facilities in order to attract tourists and increase economic development. During the late 1980s a sustainable development approach to tourism planning was advanced by a number of authors (Azimi $\&$ hajipour, 2010). In the meantime, a new trend in tourism is ecotourism. The beautiful landscapes of nature and tourist attractions are the focus of this type of tourism, so it's important role in protecting the environment is essential to achieve sustainable development (Rezvani, 2002). Ecotourism is a short
"Ecological Tourism" and the new trend in tourism is a relatively recent phenomenon that only makes up a part of this industry (Zarabi et al., 2011), and as the rapid development of the tourism industry compared to the biggest mass tourism or old. The association of ecotourism; better to reduce the country's deficit and capital gains, job creation and sustainable local food (Zhuang, liu, 2010). The department of tourism benefits the local, regional, national and international causes (voeks \& ramation, 2004). The historical origin of the ecotourism concept can be traced back to the 1960 s when ecologists and environmentalists became concerned over the inappropriate use of natural resources. The preservation of biodiversity was threatened in favor of economic interest and the exploitation of natural resources (Higham, 2007). The fourth and fifth principles are related to financial benefits that may occur from ecotourism for conservation, impacting local people as well as private industry. Ecotourism has high financial potential for natural conservation through entrance fees, levies, concessions and other economic activities. The economic benefits from ecotourism can also benefit environmental conservation and 
community livelihoods (rachmawati, 2016). The definition of ecotourism is "the responsible travel to natural areas that conserves the environment and sustains the well-being of local people" (TIES, 2015).

\section{2- $\quad$ Principles of ecotourism}

More specifically, ecotourism refers to tourism to areas of natural and cultural heritage that is planned and managed with the following objectives:

1) Minimizing negative social, cultural and environmental impacts.

2) Maximizing the involvement in, and the equitable distribution of economic benefits to, host communities.

3) Maximizing revenues for re-investment in conservation.

4) Educating both visitors and local people as to the importance of

$$
N=\frac{\frac{t^{2} p q}{d^{2}}}{1+\frac{1}{n}}\left[\frac{t^{2} p q}{d^{2}}-1\right]
$$

Questionnaire based on Likert scale questionnaire developed and validated by Cronbach's alpha and this conserving natural and cultural resources.

5) Delivering a quality experience for tourists (IUCN, 2002).

Ecotourism planning involves aspects of both environmental planning and tourism planning. Components of the former include environmental protection, resource conservation and environmental impact assessment while tourism planning provides aspects of area development and social assessment (Fennell \& Dowling, 2003).

\section{3- Materials and Methods}

The purpose of this study, the type of application and the nature and methodology of the study was descriptive, analytical. Data collection methods in the study of library and field methods. The sample size was calculated using Cochran's method with error 0.05 and $0.95,322.53$ samples were found to achieve better results (Hafeznia, 2006), the sample size was increased to 360 .

was calculated using equation (2) is obtained. 
Equation 2: The Formula of Alpha Cronbach

$\boldsymbol{r}_{a}=\left[\frac{k}{k-1}\right]\left[1-\frac{\sum \sigma_{j}^{2}}{\sigma 2}\right]$

In this formula, $\boldsymbol{r}_{a}$ the total test coefficient, $k$ the number of questions, $\sigma_{\mathrm{j}}^{2}$ the variance of questions and $\sigma^{2}$ the variance of total questions (Momeni, 2007). And to analyze the strengths, weaknesses as internal factors and opportunities, Threats as external factors was used the model of strategic planning (SWOT) and the strategies and priorities of the strategic plan were quantity.

\section{4- District Geographical Situation}

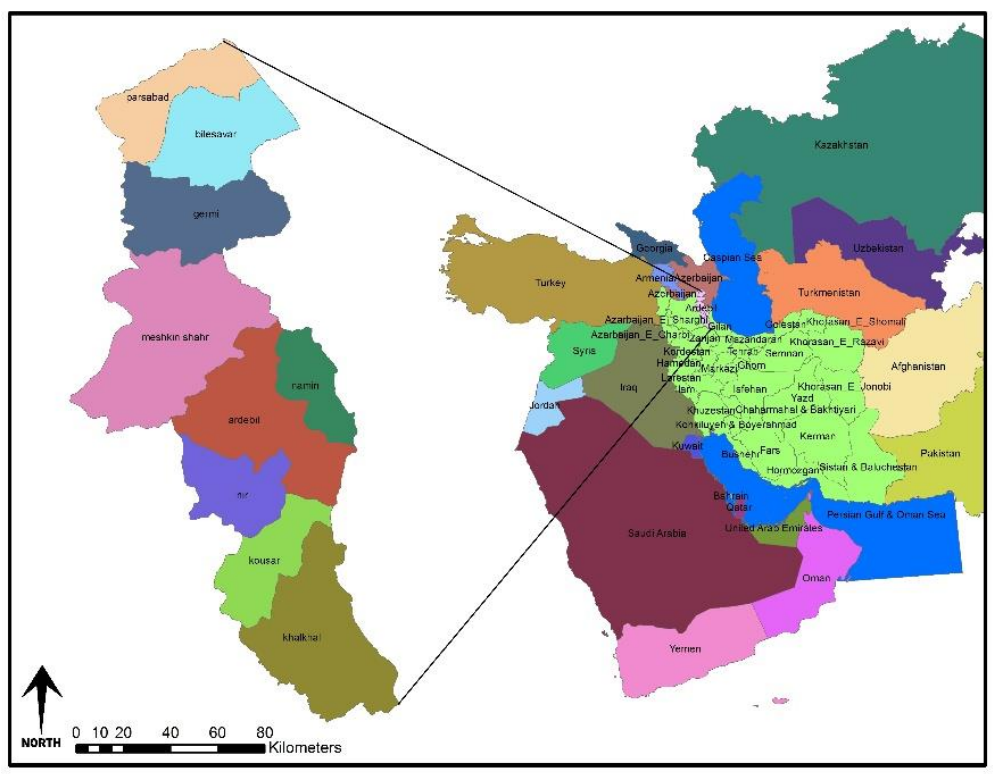

Fig.1. Location map of the case study
Ardabil province, with more than 18,500 square kilometers, is a percentage of the total area of the country of Iran (Abdollahi, 2009). The territory of the country, including attractions, cultural, social, and natural history are numerous. Certain geological and topographical conditions of the region's natural landscapes and attractive building, which represents the natural richness of the region (Pantea \& Roodsari, 2009). 
5- The method of SWOT Analysis

The SWOT first four words strengths, weaknesses, opportunities and threats (Ziari, 2004). The rationale for this approach is an effective strategy to the system must maximize strengths and opportunities, weaknesses and threats to a minimum (Hekmatnia \& Mousavi, 2008).

To construct a matrix of strengths, opportunities, weaknesses and threats should be eight stages:

1) A list of major opportunities in the external environment;

2) A list of the major threats in the external environment;

9)

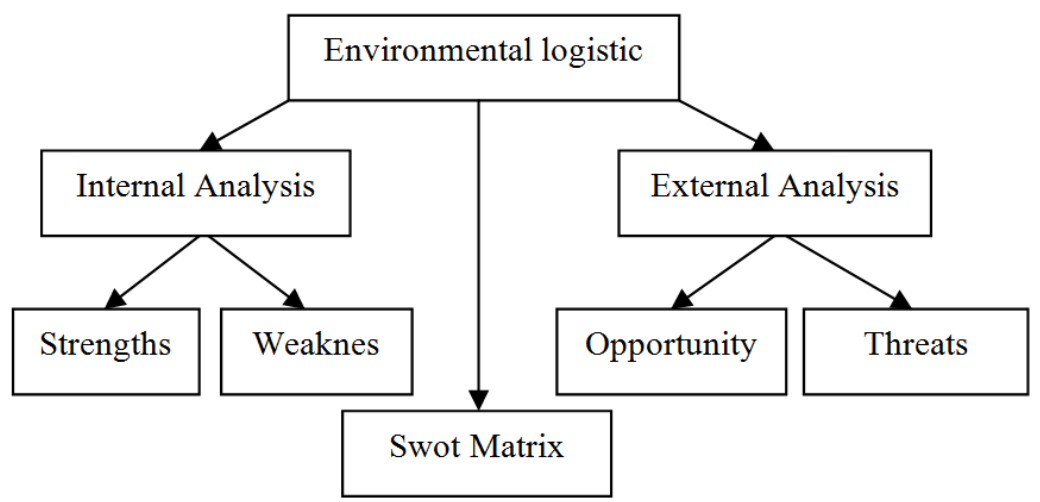

Fig. 2. The SWOT analysis flowchart

To develop a strategy for SWOT model a matrix of factors that can create a SWOT matrix or evaluation matrix is known. In this way, the evaluation of environmental opportunities and threats, strengths and
3) A list of the organization's internal strengths;

4) A list of the major internal weaknesses;

5) Internal strengths and external opportunities and results are compared with the SO group strategy is written;

6) Internal weaknesses and the opportunities available outside of the group can be written as WO strategies;

7) Internal strengths with external threats and the results of the ST Groups strategy is written;

8) Internal weaknesses with external threats and the results compared with the WT Groups strategy is written (Ebrahimzadeh et al., 2009). 
the technique of Quantitative Strategic Planning Matrix (QSPM) determines relative attractiveness of strategies. For this purpose, major external opportunities and threats, and internal strengths and weaknesses are written down in the right-side column of the strategic planning matrix. The information is obtained directly from the internal and external factors evaluation matrixes. A weight or coefficient is assigned to the external and internal factors which play an important role in the system's success (shiehbeiki \& et al, 2014).

\section{6- External and Internal Factors} Evaluation Matrix (EFEM and IFEM) and its steps

Strategic Planners using an internal and external Factors evaluated and at the same time, using the IFEM between different subjects have been identified, evaluated, and solutions for them. five steps have been done to prepare a table of external and internal factors and how they affect the functions of ecotourism development of ecotourism province in ardebil province:
In the first column (table 1-4), external factors (opportunities and threats) and internal (strengths and weaknesses) facing the system was developed.

- $\quad$ In the second column (table 1-4), to each EFEM and IFEM that might influence their strategic position in the system, weighting from " 1 " (most important) to "0" (the most unimportant) do. No matter how much weight is in the effect on the current situation and future systems will be higher.

In the third column (table 1-4) of each external and internal factors on the importance and location of the current system, the degree to which a particular factor 4 (very good) to 1 (poor) feeds. In this ranking, the position of each agent is determined by the system.

In the fourth column of each external and internal factors, the weight of each factor in its ranking (column $2 \times$ column 3) we multiply thereby the weighted scores obtained.

- $\quad$ The weighted scores in the fourth column separately and summed weighted scores for each of the internal and external factors to calculate ( Ebrahimzadeh et al ., 2009 ). In the evaluation matrix, never a final score total of 4 or more and never less than 1 
Periódico do Núcleo de Estudos e Pesquisas sobre Gênero e Direito

Centro de Ciências Jurídicas - Universidade Federal da Paraíba

V. 8 - $\mathrm{N}^{\circ} 03$ - Ano 2019

ISSN | 2179-7137 | http://periodicos.ufpb.br/ojs2/index.php/ged/index

unlikely. The average of this sum is 2.5 .

important (Behzadfar \& Zamanian,

If it is higher, it is more importance is

2008).

more and less important if it is less

Table 1: Summary of strengths analysis

\begin{tabular}{|c|c|c|c|c|c|}
\hline strengths & Mean Rank & Weight & Gradation & $\begin{array}{l}\text { Weight } \\
\text { prominence }\end{array}$ & rank \\
\hline $\begin{array}{l}\text { S1:Existence of high potential in terms of foreign Ecotourist } \\
\text { attract }\end{array}$ & 4.28 & 0.070 & 2 & 0.14 & 13 \\
\hline S2: hot springs of Ardabil & 4.43 & 0.072 & 2 & 0.14 & 14 \\
\hline S3: Existence of certain culture and traditions of the people & 3.77 & 0.061 & 4 & 0.24 & 3 \\
\hline $\begin{array}{l}\text { S4:Existence of special kinds of local handicrafts ( carpets, } \\
\text { varnished, rugs, etc) }\end{array}$ & 3.77 & 0.062 & 3 & 0.18 & 7 \\
\hline S5: biodiversity in flora and fauna ( plant and animal diversity) & 3.80 & 0.062 & 3 & 0.18 & 9 \\
\hline $\begin{array}{l}\text { S6: Existence of potential for geotourism in the region, such as } \\
\text { caves, valleys and etc }\end{array}$ & 3.79 & 0.062 & 3 & 0.18 & 8 \\
\hline S7: different weather in other parts of the country (cool summer) & 4.84 & 0.079 & 2 & 0.15 & 12 \\
\hline S8: Existence of variety of special attractions for ecotourism & 3.89 & 0.064 & 3 & 0.19 & 5 \\
\hline S9: be hospitable locals & 3.74 & 0.061 & 4 & 0.24 & 2 \\
\hline $\begin{array}{l}\text { S10: green valleys and a great variety of fruit orchards in the } \\
\text { province. }\end{array}$ & 4.13 & 0.067 & 4 & 0.27 & 1 \\
\hline $\begin{array}{l}\text { S11: Existence of souvenirs, fruits and local snacks ( honey, } \\
\text { etc) and offer it to tourists }\end{array}$ & 4.18 & 0.068 & 3 & 0.20 & 4 \\
\hline $\begin{array}{l}\text { S12:Shahsevan nomadic Attraction as one of tribe the most } \\
\text { important }\end{array}$ & 3.81 & 0.062 & 3 & 0.18 & 11 \\
\hline $\begin{array}{l}\text { S13: the existence of rural tourism in the ecotourism (Barandagh } \\
\text {, Kzj and ...) }\end{array}$ & 3.81 & 0.062 & 3 & 0.18 & 10 \\
\hline S14: a calm and serene environment. & 4.04 & 0.066 & 3 & 0.19 & 6 \\
\hline $\begin{array}{l}\text { S15: sabalan mountain Potential as a special attraction in the } \\
\text { province and the country. }\end{array}$ & 4.49 & 0.073 & 2 & 0.14 & 15 \\
\hline Total & 60.76 & 1 & - & 2.89 & - \\
\hline
\end{tabular}

Table 2: The summary of Weakness analysis

\begin{tabular}{|l|l|l|l|l|l|}
\hline weakness & Mean Rank & Weight & Gradation & $\begin{array}{l}\text { Weight } \\
\text { prominence }\end{array}$ & rank \\
\hline $\begin{array}{l}\text { W1: The use of expert and experienced in the } \\
\text { Ecotourist, along with other areas of tourism }\end{array}$ & 2.81 & 0.073 & 4 & 0.29 & 7 \\
\hline W2: the satisfaction of a visit to Ardabil & 4.10 & 0.10 & 4 & 0.40 & 1 \\
\hline $\begin{array}{l}\text { W3: facilitate the development of ecotourism ( such as } \\
\text { roads, services and the way ) in Ardabil province }\end{array}$ & 3.06 & 0.080 & 4 & 0.32 & 4 \\
\hline $\begin{array}{l}\text { W4: exploiting the opportunities of ecotourism of } \\
\text { Ardabil }\end{array}$ & 2.88 & 0.075 & 3 & 0.22 & 12 \\
\hline W5: Marketing natural attractions of Ardabil & 3.01 & 0.078 & 4 & 0.31 & 5 \\
\hline
\end{tabular}


Periódico do Núcleo de Estudos e Pesquisas sobre Gênero e Direito Centro de Ciências Jurídicas - Universidade Federal da Paraíba

V. 8 - $\mathrm{N}^{\circ} 03$ - Ano 2019

ISSN | 2179-7137 | http://periodicos.ufpb.br/ojs2/index.php/ged/index

\begin{tabular}{|l|l|l|l|l|l|}
\hline $\begin{array}{l}\text { W6: how to manage ecotourism attractions of the } \\
\text { governmental organizations }\end{array}$ & 2.94 & 0.076 & 4 & 0.30 & 6 \\
\hline $\begin{array}{l}\text { W7: The existence capabilities and potentials of Sports } \\
\text { ecotourism (skiing, hiking in the canyons, riding and } \\
\text { kite ... }\end{array}$ & 3.47 & 0.090 & 4 & 0.36 & 3 \\
\hline $\begin{array}{l}\text { W8: historical and cultural attractions in the } \\
\text { ecotourism attractions }\end{array}$ & 3.72 & 0.097 & 4 & 0.39 & 2 \\
\hline $\begin{array}{l}\text { 9W: Due to the meetings and conference officials to } \\
\text { develop ecotourism }\end{array}$ & 2.79 & 0.073 & 3 & 0.22 & 11 \\
\hline $\begin{array}{l}\text { W10: Planning and government investment in } \\
\text { ecotourism }\end{array}$ & 2.85 & 0.074 & 3 & 0.23 & 10 \\
\hline $\begin{array}{l}\text { W11: Diversifying tourism products to attract Most } \\
\text { tourists by organizations and private enterprises }\end{array}$ & 3.08 & 0.080 & 3 & 0.24 & 9 \\
\hline W12: how to deal with local passengers & 3.46 & 0.090 & 3 & 0.27 & 8 \\
\hline Total & 38.19 & 1 & - & 3.55 & - \\
\hline
\end{tabular}

Table 3: The summary of Opportunity's analysis

\begin{tabular}{|c|c|c|c|c|c|}
\hline Opportunity & Mean Rank & Weight & Gradation & $\begin{array}{l}\text { Weight } \\
\text { prominence }\end{array}$ & rank \\
\hline O1: proper climatic conditions in comfort climate & 4.08 & 0.078 & 3 & 0.23 & 8 \\
\hline O2: unique spas in the country & 4.48 & 0.086 & 2 & 0.17 & 13 \\
\hline O3: rich cultural experiences and guest host population & 3.67 & 0.071 & 4 & 0.28 & 3 \\
\hline $\begin{array}{l}\text { O4: tourist attraction important places in nearby } \\
\text { provinces such as the North Country }\end{array}$ & 4.17 & 0.080 & 3 & 0.24 & 6 \\
\hline $\begin{array}{l}\text { O5: beyond the economic interests of both local and } \\
\text { foreign income and to the development of ecotourism }\end{array}$ & 3.91 & 0.075 & 4 & 0.30 & 1 \\
\hline $\begin{array}{l}\text { O6: promoting employment through the creation of } \\
\text { touristy attraction force organizations to develop } \\
\text { tourism jobs }\end{array}$ & 2.72 & 0.052 & 4 & 0.21 & 9 \\
\hline $\begin{array}{l}\text { O7: Increase the welfare and quality of life of local } \\
\text { people through ecotourism development with income }\end{array}$ & 3 & 0.058 & 4 & 0.23 & 7 \\
\hline $\begin{array}{l}\text { O8: restoring and preserving local traditions associated } \\
\text { with the development of cultural and historical heritage } \\
\text { and natural attractions }\end{array}$ & 3.52 & 0.068 & 3 & 0.20 & 10 \\
\hline $\begin{array}{l}\text { O9: The role of ecotourism in conservation of natural } \\
\text { resources by encouraging tourists and people }\end{array}$ & 3.34 & 0.064 & 3 & 0.19 & 12 \\
\hline O10: Near the province of Azerbaijan & 4.42 & 0.085 & 3 & 0.25 & 5 \\
\hline $\begin{array}{l}\text { O11: possible to design and tooling of natural potential } \\
\text { to create artificial gravity and manmade attractions } \\
\text { along with }\end{array}$ & 3.30 & 0.063 & 3 & 0.19 & 11 \\
\hline $\begin{array}{l}\text { O12: reception of the foreign investment - domestic } \\
\text { and regional ecotourism development for effective use } \\
\text { of resources }\end{array}$ & 3.30 & 0.063 & 4 & 0.25 & 4 \\
\hline $\begin{array}{l}\text { O13: the natural attractions of interest to tourists to } \\
\text { visit the province. }\end{array}$ & 4.24 & 0.15 & 2 & 0.30 & 2 \\
\hline Total & 51.68 & 1 & - & 3.39 & - \\
\hline
\end{tabular}


Periódico do Núcleo de Estudos e Pesquisas sobre Gênero e Direito

Centro de Ciências Jurídicas - Universidade Federal da Paraíba

V. 8 - $\mathrm{N}^{\circ} 03$ - Ano 2019

ISSN | 2179-7137 | http://periodicos.ufpb.br/ojs2/index.php/ged/index

Table 4: The summary of Threats analysis

\begin{tabular}{|c|c|c|c|c|c|}
\hline Threats & Mean Rank & Weight & Gradation & $\begin{array}{l}\text { Weight } \\
\text { prominence }\end{array}$ & rank \\
\hline $\begin{array}{l}\text { T1: many remain unknown ecotourism attraction } \\
\text { Ardebil }\end{array}$ & 2.94 & 0.12 & 4 & 0.48 & 4 \\
\hline $\begin{array}{l}\text { T2: proper planning for the use of natural features and } \\
\text { capabilities }\end{array}$ & 3.03 & 0.13 & 3 & 0.39 & 5 \\
\hline $\begin{array}{l}\text { T3: dealing with the agencies responsible for } \\
\text { environmental violations }\end{array}$ & 2.82 & 0.12 & 4 & 0.48 & 2 \\
\hline $\begin{array}{l}\text { T4: destruction of natural vegetation by pastures and } \\
\text { woods dusts }\end{array}$ & 2.84 & 0.12 & 4 & 0.48 & 3 \\
\hline $\begin{array}{l}\text { T5: land use conversion to other land uses incompatible } \\
\text { with natural and ecological environment }\end{array}$ & 2.78 & 0.11 & 3 & 0.33 & 7 \\
\hline $\begin{array}{l}\text { T6: funding organizations and agencies in the region, } \\
\text { especially in the field of ecotourism and tourism } \\
\text { investment }\end{array}$ & 2.68 & 0.11 & 3 & 0.33 & 6 \\
\hline $\begin{array}{l}\text { T7: social violence and crime increased with the arrival } \\
\text { of tourists to the tourism sites in natural areas }\end{array}$ & 2.82 & 0.12 & 4 & 0.48 & 1 \\
\hline $\begin{array}{l}\text { T8: increasing the price of goods and services by } \\
\text { tourists }\end{array}$ & 3.28 & 0.14 & 2 & 0.28 & 8 \\
\hline Total & 23.18 & 1 & - & 3.25 & - \\
\hline
\end{tabular}

7- $\quad$ SWOT matrix for strategic and

\section{operational priorities}

To analyze the internal and external factors, internal and external matrix is used as a tool. If the matrix is a grid matrix of scores for both internal and external factors of less than 2.5 if the home will have 3 tables defensive position. Scores for both the matrix and the higher grades of 2.5 is 2 and the position of the home would be invasive and internal factors of the matrix score of 2.5 and external factors matrix score less than 2.5 on the competitive position of the organization is located and if it is out of the counter is the conservative position (Dehghani et al., 2009).

Table 5: External and internal factors Evaluation matrix

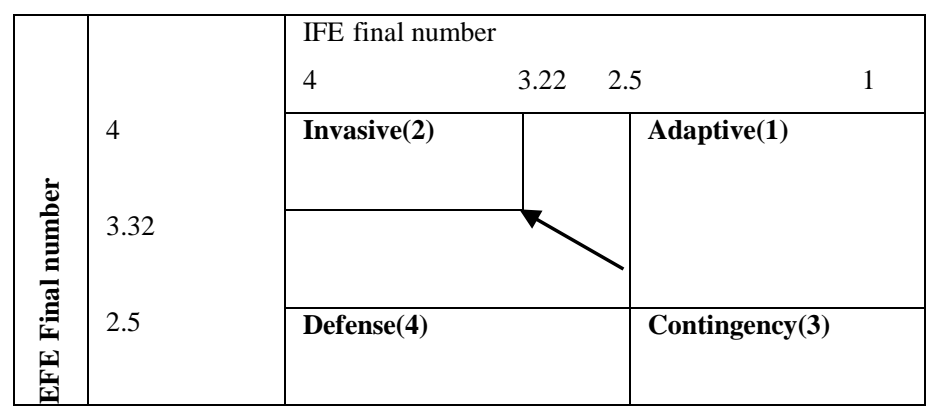




\section{8- $\quad$ Stages of implementation and strategies}

This step has two parts. The First stage of compiling is done through a SWOT matrix choice strategies is then acceptable level, through internal and external matrix is done as follows. Depending on the system, four different strategies which can be formulated in terms of degrees active.

Table 6: SWOT analysis

\begin{tabular}{|r|r|r|r|}
\hline \multicolumn{2}{|r}{ The four strategies indoor swot analysis } & \multicolumn{2}{|c|}{ Internal Environment } \\
\cline { 3 - 4 } Wxternal & Opportunities & Strengths & Anvasive strategy (SO) ( max - max) \\
Environment & & & Adaptive strategy (WO) \\
\cline { 2 - 4 } & threats & contingency strategy (ST) ( max - min ) & Defense strategy (WT) ( min - min ) \\
\hline
\end{tabular}

(Ebrahimzaheh et al., 2009)

\section{8-1- Invasive strategy (SO)}

- $\quad \mathrm{SO}_{1}$ : rational use of the potential of ecotourism with special interest for the development $\left(S_{1}, S_{2}, S_{6}, S_{7}, S_{8}, S_{10}, S_{15}\right.$, $\mathrm{O}_{1}, \mathrm{O}_{2}, \mathrm{O}_{5}$ and $\mathrm{O}_{6}$ )

$\mathrm{SO}_{2}$ : Increase the quality and quantity of cultural attractions along with local communities to develop ecotourism $\left(\mathrm{S}_{3}, \mathrm{~S}_{4}, \mathrm{O}_{3}, \mathrm{O}_{7}\right.$ and $\left.\mathrm{O}_{8}\right)$

- $\quad \mathrm{SO}_{3}$ : Setting up and developing the quality and quantity of communication facility specifically for ease of travel $\left(\mathrm{S}_{8}, \mathrm{~S}_{12}, \mathrm{~S}_{13}, \mathrm{~S}_{15}, \mathrm{O}_{4}, \mathrm{O}_{5}, \mathrm{O}_{6}, \mathrm{O}_{10}\right.$, $\mathrm{O}_{12}$ and $\left.\mathrm{O}_{13}\right)$

- $\quad \mathrm{SO}_{4}$ : Create the appropriate fields (lower taxes, subsidies, etc), there is the potential for foreign investment in the field of ecotourism $\left(\mathrm{S}_{5}, \mathrm{~S}_{2}, \mathrm{~S}_{8}, \mathrm{O}_{4}, \mathrm{O}_{5}, \mathrm{O}_{6}, \mathrm{O}_{7}\right.$, $\left.\mathrm{O}_{10}, \mathrm{O}_{12}, \mathrm{O}_{11}\right)$

- $\mathrm{SO}_{5}$ : a greater propensity to attract more tourists to the province, especially in the area of potential $\left(\mathrm{S}_{1}, \mathrm{~S}_{2}\right.$, $\left.\mathrm{S}_{6}, \mathrm{~S}_{7}, \mathrm{~S}_{9}, \mathrm{~S}_{14}, \mathrm{O}_{2}, \mathrm{O}_{4}, \mathrm{O}_{10}, \mathrm{O}_{13}\right)$

$\mathrm{SO}_{6}$ : Due to the nature of the development and operation of ecotourism with conservation of the species $\left(\mathrm{S}_{5}, \mathrm{~S}_{10}, \mathrm{~S}_{8}, \mathrm{O}_{9}\right)$

- $\mathrm{SO}_{7}$ : increased attention to ecotourism in other parts of the province, due to the special feature of this part $\left(\mathrm{S}_{1}\right.$, $\mathrm{S}_{2}, \mathrm{~S}_{5}, \mathrm{~S}_{6}, \mathrm{~S}_{7}, \mathrm{~S}_{8}, \mathrm{~S}_{10}, \mathrm{~S}_{12}, \mathrm{~S}_{13}, \mathrm{~S}_{14}, \mathrm{~S}_{15}, \mathrm{O}_{1}, \mathrm{O}_{5}, \mathrm{O}_{6}$, $\left.\mathrm{O}_{7}, \mathrm{O}_{8}, \mathrm{O}_{13}, \mathrm{O}_{9}\right)$ 


\section{8-2- Adaptive strategy (WO)}

- $\mathrm{WO}_{1}$ : Increased use of expert force with appropriate management to touristy attract $\left(\mathrm{W}_{1}, \mathrm{~W}_{4}, \mathrm{~W}_{6}, \mathrm{O}_{5}, \mathrm{O}_{6}, \mathrm{O}_{7}, \mathrm{O}_{13}\right)$

$-\mathrm{WO}_{2}$ : increasing the quality of communication facilities in order to facilitate passengers traveling renewed interest in ecotourism $\left(\mathrm{W}_{2}, \mathrm{~W}_{3}, \mathrm{~W}_{12}, \mathrm{O}_{4}, \mathrm{O}_{10}\right.$ and $\mathrm{O}_{13}$ )

8

- $\mathrm{WO}_{3}$ : Widespread Propagation in and out of the province for good behavior and increase the interest of tourists to visit the province with special abilities $\left(\mathrm{W}_{5}, \mathrm{~W}_{9}, \mathrm{~W}_{12}, \mathrm{O}_{7}, \mathrm{O}_{8}, \mathrm{O}_{11}, \mathrm{O}_{13}\right)$

- $\mathrm{WO}_{4}$ : Identify the nature and diversification of packages due to the development circumstances of the case $\left(\mathrm{W}_{4}, \mathrm{~W}_{8}, \mathrm{~W}_{9}, \mathrm{~W}_{11}, \mathrm{O}_{11}, \mathrm{O}_{12}\right)$

- $\mathrm{WO}_{5}$ : increased investment to develop leisure - Sport facilities for development of ecotourism in the region of potential $\left(\mathrm{W}_{7}, \mathrm{~W}_{8}, \mathrm{~W}_{9}, \mathrm{~W}_{10}, \mathrm{O}_{9}, \mathrm{O}_{8}, \mathrm{O}_{7}, \mathrm{O}_{6}, \mathrm{O}_{5}, \mathrm{O}_{3}\right)$

- $\mathrm{WO}_{6}$ : building systems management with respect to the potential attraction of the special attractions in the province $\left(\mathrm{W}_{1}, \mathrm{~W}_{4}, \mathrm{~W}_{6}, \mathrm{~W}_{10}, \mathrm{O}_{2}, \mathrm{O}_{4}, \mathrm{O}_{9}, \mathrm{O}_{12}, \mathrm{O}_{13}\right)$

\section{8-3- Contingency strategy (ST)}

- $\mathrm{ST}_{1}$ : organizations funding Increase to utilize the functionality of ecotourism in8-5 the area with appropriate planning $\left(\mathrm{S}_{1}, \mathrm{~S}_{2}\right.$, $\left.\mathrm{S}_{3}, \mathrm{~S}_{6}, \mathrm{~S}_{7}, \mathrm{~S}_{15}, \mathrm{~T}_{6}, \mathrm{~T}_{2}, \mathrm{~T}_{5}\right)$
- ST2: Internal and external strengthen advertising and culture in the province and outside the province to identify the specific interests at region $\left(S_{15}, S_{3}, S_{4}, S_{7}\right.$, $\mathrm{S}_{1}, \mathrm{~S}_{8}, \mathrm{~S}_{9}, \mathrm{~S}_{12}, \mathrm{~T}_{1}, \mathrm{~T}_{7}$ and $\mathrm{T}_{8)}$

- $\mathrm{ST}_{3}$ : dealing with offenders in the most ecotourism locations for appropriate attractions $\left(\mathrm{S}_{14}, \mathrm{~S}_{10}, \mathrm{~S}_{5}, \mathrm{~S}_{3}, \mathrm{~T}_{3}, \mathrm{~T}_{4}, \mathrm{~T}_{5}, \mathrm{~T}_{7}\right)$

\section{8-4- Defense strategy (WT)}

- $\mathrm{WT}_{1}$ : increased recruitment of specialized programs tailored to identify the attractiveness and potential of the region $\left(\mathrm{W}_{1}, \mathrm{~W}_{4}, \mathrm{~W}_{6}, \mathrm{~W}_{7}, \mathrm{~W}_{9}, \mathrm{~T}_{1}\right.$ and $\left.\mathrm{T}_{2}\right)$

- $\mathrm{WT}_{2}$ : development of optimal management and treatment of offenders as basic $\left(\mathrm{W}_{8}, \mathrm{~W}_{7}, \mathrm{~W}_{6}, \mathrm{~W}_{4}, \mathrm{~T}_{3}, \mathrm{~T}_{5}, \mathrm{~T}_{4}, \mathrm{~T}_{7}\right)$

- $\mathrm{WT}_{3}$ : Increase inter-provincial and intraprovincial publicity to identify and culture along with a variety of capabilities in the region $\left(\mathrm{W}_{2}, \mathrm{~W}_{5}, \mathrm{~W}_{9}, \mathrm{~W}_{11}\right.$, $\mathrm{W}_{12}, \mathrm{~T}_{8}, \mathrm{~T}_{7}$ and $\mathrm{T}_{1}$ )

- $\mathrm{WT}_{4}$ : more investment in developed areas with more ecotourism attractions $\left(\mathrm{W}_{11}, \mathrm{~W}_{10}, \mathrm{~W}_{4}, \mathrm{~T}_{6}, \mathrm{~T}_{2}\right)$

- WT5: increase efficient communication and recreation - sports facilities and ecotourism development in order to avoid the violations taking place in isolation $\left(\mathrm{W}_{3}, \mathrm{~W}_{2}, \mathrm{~W}_{8}, \mathrm{~W}_{7}, \mathrm{~T}_{5}, \mathrm{~T}_{4}, \mathrm{~T}_{3}, \mathrm{~T}_{8}, \mathrm{~T}_{7}\right)$

Quantitative strategic planning (acceptable strategies prioritizing) 
This step is performed according to the following:

- Information elements (S, O, W, T) and weighted score from summarize tables the SWOT analysis matrix table will be moved to external and internal factors.

- All of strategy and strategic planning in the columns of the matrix is written above horizontally.
- AS important factor is that the 1-4 score the importance of each factor in the strategy have been developed. $(1=$ not important, $2=$ less important, $3=$ moderately important, 4 = very important)

- Total Significance Coefficient (TAS) is equal to the weight multiplied Score AS. - TAS are collected at the end of the assignment the best priority defines the order (nohegar et al., 2009).

Table 7: Quantitative strategic planning Model (QSPM)

\begin{tabular}{|c|c|c|c|c|c|c|c|c|c|c|c|c|c|c|c|c|c|c|c|}
\hline \multirow{3}{*}{ factor } & \multirow{3}{*}{$\begin{array}{l}\text { Weight } \\
\text { score }\end{array}$} & \multicolumn{14}{|l|}{ SO } & \multicolumn{2}{|l|}{ Wo } & \multirow[t]{3}{*}{ ST } & \multirow[t]{3}{*}{ WT } \\
\hline & & \multicolumn{2}{|l|}{$\mathrm{SO}_{1}$} & \multicolumn{2}{|c|}{$\mathrm{SO}_{2}$} & \multicolumn{2}{|l|}{$\mathrm{SO}_{3}$} & \multicolumn{2}{|c|}{$\mathrm{SO}_{4}$} & \multicolumn{2}{|c|}{$\mathrm{SO}_{5}$} & \multicolumn{2}{|c|}{$\mathrm{SO}_{6}$} & \multicolumn{2}{|c|}{$\mathrm{SO}_{7}$} & & & & \\
\hline & & AS & TAS & AS & TAS & AS & TAS & AS & TAS & AS & TAS & AS & TAS & AS & TAS & & & & \\
\hline $\mathrm{S}_{1}$ & 0.14 & 4 & 0.56 & 2 & 0.28 & 2 & 0.28 & 2 & 0.28 & 4 & 0.56 & 1 & 0.14 & 3 & 0.42 & & & & \\
\hline $\mathrm{S}_{2}$ & 0.14 & & & & & & & & & & & & & & & & & & \\
\hline $\mathrm{T}_{8}$ & 0.28 & 1 & 0.28 & 1 & 0.28 & 1 & 0.28 & 1 & 0.28 & 1 & 0.28 & 1 & 0.28 & 1 & $\ldots$ & & & & \\
\hline Total & & & 19.56 & & $\begin{array}{l}19.16 \\
\end{array}$ & & 23.59 & & 24.61 & & 22.63 & & 20.14 & & 21.7 & 21.19 & $\ldots$ & & \\
\hline
\end{tabular}

Table 8: The Optimize of development Ecotourism

\begin{tabular}{|l|l|}
\hline The Optimize of development Ecotourism in Ardabil & Preference \\
\hline $\begin{array}{l}\text { Create the appropriate fields ( lower taxes, subsidies, etc), there is the potential for foreign } \\
\text { investment in the field of ecotourism }\end{array}$ & 1 \\
\hline Building system management with respect to the potential of the special attractions & 2 \\
\hline $\begin{array}{l}\text { Setting up and developing the quality and quantity of communication facility specifically } \\
\text { for ease of travel }\end{array}$ & 3 \\
\hline $\begin{array}{l}\text { Increase the attractiveness of employing specialists to identify potential regional planning } \\
\text { development in order to avoid the violations taking place in isolation }\end{array}$ & 4 \\
\hline $\begin{array}{l}\text { Ancrease the efficiency of communication and recreation - sports facilities and ecotourism } \\
\text { potential }\end{array}$ & 5 \\
\hline $\begin{array}{l}\text { Increase inter-provincial and intra- provincial publicity to identify and culture along with } \\
\text { a variety of capabilities in the region }\end{array}$ & 7 \\
\hline
\end{tabular}




\begin{tabular}{|c|c|}
\hline $\begin{array}{l}\text { Increased investment to develop leisure facilities - Sport for development of ecotourism } \\
\text { attraction in the area }\end{array}$ & 8 \\
\hline $\begin{array}{l}\text { Wide publicity at home and abroad for good behavior and increase the willingness of } \\
\text { tourists to travel to the provinces with Special Features }\end{array}$ & 9 \\
\hline $\begin{array}{l}\text { The rise of ecotourism in other parts of the region due to the special features } \\
\text { Willingness }\end{array}$ & 10 \\
\hline $\begin{array}{l}\text { to improve and enhance existing communication facility to facilitate the travel of } \\
\text { passengers as ecotourism }\end{array}$ & 11 \\
\hline Increased use of force expert with appropriate management to attract more touristy & 12 \\
\hline $\begin{array}{l}\text { Increase inter-provincial and intra- provincial campaign to identify and culture along with } \\
\text { a variety of capabilities in the region }\end{array}$ & 13 \\
\hline Dealing with offenders in a more convenient location for ecotourism attractions & 14 \\
\hline $\begin{array}{l}\text { Increased funding organizations to utilize the functionality of ecotourism in the area, along } \\
\text { with proper planning }\end{array}$ & 15 \\
\hline Due to the nature of the operation of ecotourism with conservation of species & 16 \\
\hline $\begin{array}{l}\text { strengthen internal and external advertising To identify and in vitro culture of the region } \\
\text { with special charm }\end{array}$ & 17 \\
\hline Identify the nature and diversification of packages due to the development of these & 18 \\
\hline Reasonable use of the potential of ecotourism with special interest for the development of & 19 \\
\hline $\begin{array}{l}\text { Increase the quality and quantity of cultural attractions along with local communities to } \\
\text { develop ecotourism }\end{array}$ & 20 \\
\hline
\end{tabular}

\section{9- Conclusion}

Strategic analysis of the data, using the SWOT model was initially external and internal factors evaluation matrix was formed for each of the strengths, weaknesses, opportunities and threats were weighted and graded by the methods listed ecotourism in the province should be a setting to prevent loss and energy costs. The table summarizes the analysis of weaknesses, the main weakness of the system that ecotourism is Ardebil, Ardebil is a trip to the satisfaction of words with the hospitality of the province people is one of the main strengths, but it most tourists have little impact on satisfaction, i.e. satisfaction with a weight rating of 0.40 as the major weaknesses and exploit the opportunities for Ardebil ecotourism with a score of 0.22 is the twelfth priorities that strengthen the list of weaknesses should also be undertaken. The most important opportunity for respondents to provide great economic 
benefits for local and foreign income and the development of ecotourism with a weighted score of 0.30 and the ratings average of 3.91 in the first priority and the uniqueness of the spring mineral provinces in the Area with a score of 0.17 and weigh 0.086 to priority 13 is located. Social Delinquency offenses increased with arrive tourists to the natural tourism sites to remote areas of the province with a weighted score of 0.48 as the most significant threat is posed with tourists and increasing the price of goods and services with a weighted score of 0.28 weight 0.14 to It is considered as the least threatening. Finally, the strategy and priorities matrix for SWOT implementing determined that the Rep weighing a strategy of aggressive determination in the planning of a strategic implementation priorities and strategies identified in the strategic offensive in priority $1,3,6,10,16,19$, 20 , and strategies to revise the priorities of $2,8,9,11,12,18$ and diversification strategies, priorities 14, 15, 17 and finally Rank Defense strategies 4, 5, 7, 13 are located.

\section{References}

Abdollahi, S. (2009). Project Privacy qanli bulagh Caravanserai, Cultural Heritage, Tourism and Handicrafts Ardabil province, city MeshkinShahr.

Azimi, N., \& Hajipour, A. H. (2010). Planning the Cultural Tourism and Ecotourism Industry for Economic Development: A Case Study of Iran, Environment Sciences. Vol 6. No.1. 53-64.

Behzadfar, M., \& Zamanian, R. (2008). Strategic planning of tourism development with emphasis on the case study of product : Nishapur, International Journal of Engineering Sciences and Technology, University of Tehran, Special Issue of Architectural Engineering, Volume 19, No. 6.

Dehghani, M., Josie, A., \& Shoukri, M. G. (2009). Planning for Developing Ecotourism Faroe Islands Protected Area, National Geographic Trends in management and optimal utilization of resources, 305 .

Ebrahim Zadeh, A., \& Agassi, A.(2009).

Analysis of factors affecting tourism development in the coastal zone of Chabahar Using Strategic SWOT, urban and regional studies, the number of ninth summer, 4.

Fazelnia, GH., \& hedayati, P. (2010). Strategies for tourism development sooner Zarivar Lake, Journal of Geography and Development, No. 19. 
Fennell, D. A, \& Dowling, R(Ed). (2003).

Ecotourism Policy and Planning. CABI publishing, 11.

Godde, Pamela, m., martin, f., \& friedrich, M. (2000). Tourism and development in mountain regions" cabi publishing.

Hafeznia, M. (2006). Introduction to Research Methods in the Human Sciences, Thirteenth Edition Tehran: publisher side, 144.

Hekmatnia, H., \& Mousavi, M. (2008). Application of the Model of Urban Planning and Regional Geography, published by modern science, 293.

Higham, J(Ed). (2007). Critical Issues in Ecotourism: Understanding a complex tourism phenomenon. Elsevier, 28.

IUCN. (2002). Botswana National Ecotourism Strategy. Final report. IUCN (Botswana) and Symbiosis Consulting (Pty) Ltd, 1.

Momeni, M. (2007). Statistical Analysis Using Spss. first edition, Tehran: The New Press, 114.

Nohegar, A., HosseinZadeh, M., \& Pirasteh, A. (2009). Capability to assess the nature of the island model strategy using SWOT,
Journal of Geography and Development, No.

15.

Pantea, S., \& Roodsari, H. (2009). Ardabil

Geotourism Atlas, Geosciences website.

Parvin, M., \& Ahmadi, M. (2013).

Ecotourism Potential Measuring of mehran Province for permanent development by sequential analysis model (AHP). International Research Journal of Applied and basic Sciences, science Explorer Publications, vol(5), pp 612-615.

Pazouki, M., jozi, S.A and ziari, Y.A. (2017). Strategic management in urban environment using SWOT and QSPM, Global journal environment. Sci. manage, 3(2): 207-216.

Rachmawati, E. (2016). Financing Ecotourism Ventures to Support Climate Change Mitigation. What Should the, Financial Sector Be Doing in Regards to Climate Change?, seven pillars institute, vol.5, issue 1,pp 21-40.

Rezvani, A. A. (2002). The role of ecotourism in the Environment, Journal of Environmental Studies, No. 31, 115.

Rukn Al-Din Eftekhari, A., \& Mahdavi, D. (2006). Guidelines for rural tourism development model using SWOT: Lavasan 


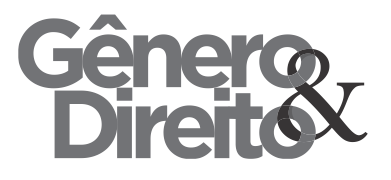

Periódico do Núcleo de Estudos e Pesquisas sobre Gênero e Direito

Centro de Ciências Jurídicas - Universidade Federal da Paraíba

V. 8 - $\mathrm{N}^{\circ} 03$ - Ano 2019

ISSN | 2179-7137 | http://periodicos.ufpb.br/ojs2/index.php/ged/index small village, Journal of Human Sciences

Lecturer, No. 45.

Shiebeiki, sh., abbaspour, M., monavari, S.M., arjmandi, R \& Lahijanian, A. (2014).

Public Participation Role in Sustainable

Urban Management by Quantitative Strategic Planning Matrix (QSPM), Int. J. Environ. Res., 8(4):1309-1314.

TIES. (2015). TIES Global Ecotourism Fact Sheet. Www. Ecotourism .com.

Voeks, R. (2004). The providence of nature: valuing ecosystem service. vol.1, NO.2, international journal of environmental science \& technology, 158.

Zahedi, S. (2004). Based on sustainable tourism and ecotourism (with an emphasis on the environment), Allameh Tabatabai University.

Zarabi, A., Movahedi, S., \& Rakhshani Nasab, H. (2011). The application of cluster analysis in the spatial analysis of ecotourism (Case Study: Sistan ecotourism. Environmental Science, Year VII Number IV.

Zhuang, X., \& Huiyan, L. (2010). some suggestions for community-based ecotourism managment. 2010 IEEE, 1.
Ziari, K. (2004). Schools, theories and models in regional planning, Yazd University Press, 238 